\title{
CHARACTERISTICS OF BLOOMING, FLORAL NECTARIES AND NECTAR OF Malus sargentii Rehd.
}

\author{
Elżbieta Weryszko-Chmielewska, Marta Dmitruk
}

\author{
Department of Botany, University of Life Sciences in Lublin, Akademicka 15, 20-950 Lublin, Poland \\ e-mail: elzbieta.weryszko@up.lublin.pl
}

Received: 15.02.2009

\begin{abstract}
In the years 2007-2008, the flowering biology of $M a$ lus sargentii, an ornamental apple tree native to Japan, was studied in the conditions of Lublin (Poland). The daily rate of flower opening, flowering duration and flower visitation by insects were determined. The amount of nectar produced per flower and sugar content in the nectar were investigated. The size of nectaries and the micromorphology of their surface were examined using light and scanning electron microscopy. It was found that the greatest amount of flowers opened between 11.00 and 13.00. During this time, the largest number of insects was observed in the flowers. Bees (90\%) were predominant among the insects, with a much smaller number of bumblebees (6\%) and butterflies (4\%). The flower life span was 5 days. Over this period, the flower produced, on the average, $0.71 \mathrm{mg}$ of nectar with an average sugar content of $32 \%$. The nectaries of Malus sargentii are orange-yellow coloured and they represent the hypanthial type. Due to the protrusion of the nectariferous tissue, they are classified as automorphic nectaries. The surface of the epidermal cells of the nectary was distinguished by distinct cuticle folds. A small number of stomata were located only in the basal part of the nectary. At the beginning of flowering, all stomata were closed, but secretion traces were observed near well-developed outer cuticular ledges.
\end{abstract}

Key words: blooming, diurnal dynamics, visiting insects, nectary, micromorphology, nectar amount

\section{INTRODUCTION}

Malus sargentii Rehd. belongs to beautiful ornamental apple trees which are planted in gardens and city parks. It comes from Japan. This is a dwarf tree of up to $2 \mathrm{~m}$ in height, with a spherical crown. Its leaves are ovate, lobed. In autumn they turn yellow and orange, which is one of its ornamental values. In buds flowers are carmine-pink, and during flowering they are white. Due to the uneven development of flowers, alongside coloured buds flowers with white petals occur on the tree. Red, shining fruits with a diameter of up to $1 \mathrm{~cm}$, growing on long, thin stalks, also contribute to the ornamental value of this tree (B u g a $\nmid$ a , 2000).

Malus sargentii fruits are used for ornamental plant arrangements and for decorating confectionary products. This species is utilized as one of pollinators in commercial orchards.

Different apple species are recognised as an important source of nectar ( $\mathrm{J}$ a b ł o ń s k i , 1986; G u lyás et al. 1989; Gadawski and Smith, 1992; Orosz-Kovács et al. 1997; Nagy Tóth et al. 2000; K ołtowski, 2006). Ornamental apple trees are distinguished by different sizes of nectaries and varied structure of their surface (K o n a r s k a, 2007). The present study on Malus sargentii is a continuation of our research on the size and structure of floral nectaries as well as on the nectar production rate of different species of the family Rosaceae, subfamily Pomoideae. Our previous studies related to the species Chaenomeles, Cydonia, Malus, Pyrus (W e r y s z k o- C h mi elewska and Konarska, 1995), Cotoneaster, Crataegus, Sorbus (Werys zko-Chmielewska and Konarska, 1996; WeryszkoChmielewska et al. 1996), Chaenomeles, Cydonia, Aronia (Wery s z k - Chmie lew ska et al. 1997), Crataegus (Wery s zko-Chmielew ska et al. 2003), Pyrus (K o n a r s k a et al. 2005), Sorbus (Weryszko-Chmielewska and Konars k a, 2006), Crataegus (Ch wil et al. 2006).

The aim of the study was to determine the size and micromorphology of the floral nectary of Malus sargentii and to estimate the nectar production rate in this species as well as to compare the investigated traits with previously obtained results for other species from the same family and subfamily. 


\section{MATERIALS AND METHODS}

The study on flowering of Malus sargentii Rehd. was conducted in an arboretum of the Botanical Garden in Lublin in the years 2007-2008. Tree flowering duration and the life span of a flower were investigated. The daily rate of flower opening, flower visitation by insects and nectar production rate were determined.

The weight of nectar secreted was examined using the pipette method ( $\mathrm{J}$ a b ł on s ki and $\mathrm{Szk}$ la n o w s k a , 1979). 10 samples were collected; a single sample contained the nectar produced by 10-30 flowers. The percentage sugar content in the nectar was determined using the Abbe refractometer. The average weight of sugars produced by 10 flowers was calculated.

The nectary size was investigated under a light microscope using semi-permanent slides which had been prepared from manually cut sections. Longitudinal sections of the lower part of the flowers were made, containing the hypanthium with the ovary. The radial length of the nectariferous tissue and its maximum thickness were determined.

In flowers collected at the beginning of anthesis, the micromorphology of the nectary surface was examined using scanning electron microscopy (SEM) in accordance with the method described by W e ry s zk o-Chmielew s k a et al. (2003). The location of stomata and their type were determined.

\section{RESULTS}

\section{The daily rate of flower opening and insect visitation}

Malus sargentii blooms very abundantly (Fig. 1A). The tree flowering period was determined to be 15 days, and the flower life span, under the study conditions, was 5 days (4-6). Flowering started in the first decade of May, with the full bloom stage at the beginning of the second decade of May.

Malus sargentii produces flowers with white petals (Figs 1A, B) whose diameter was $1.5-3 \mathrm{~cm}$, on the average $2.5 \mathrm{~cm}$. The outer part of petals has pink colour only in buds, and it disappears before the start of flowering. The daily rate of flower opening was different on the respective study days, which was associated with the variability in weather conditions. However, within 3 days the largest number of open flowers was noted in afternoon hours, with the maximum between 11.00 and 13.00 (Fig. 2). Flowers were visited by insects with the greatest frequency also between 11.00 and 14.00, which corresponded to the large number of open flowers during this time and was probably also associated with intensive nectar secretion. Bees were predominant among the insects (about 90\%) (Figs 1A, $\mathrm{B})$; there were much fewer bumblebees $(6 \%)$ and butterflies (4\%).

Table 1

Nectar production per 10 flowers Malus sargentii.

\begin{tabular}{|c|c|c|c|c|c|c|}
\hline \multirow[b]{2}{*}{$\begin{array}{l}\text { Observation } \\
\text { terms }\end{array}$} & \multicolumn{2}{|c|}{$\begin{array}{l}\text { Nectar amount } \\
(\mathrm{mg})\end{array}$} & \multicolumn{2}{|c|}{$\begin{array}{l}\text { Sugars content in nectar } \\
(\%)\end{array}$} & \multicolumn{2}{|c|}{ Weight of sugars in nectar (mg) } \\
\hline & $\begin{array}{l}\text { Range } \\
\text { min.-max. }\end{array}$ & Average SD & $\begin{array}{l}\text { Range } \\
\text { min.-max. }\end{array}$ & Average SD & $\begin{array}{l}\text { Range } \\
\text { min.-max. }\end{array}$ & Average SD \\
\hline I & $7.00-9.71$ & $8.65 \pm 1.18$ & $25.00-47.00$ & $36.50 \pm 11.12$ & $2.43-4.32$ & $3.10 \pm 0.87$ \\
\hline II & $4.33-8.00$ & $6.34 \pm 1.86$ & $35.00-45.00$ & $40.00 \pm 7.07$ & $1.93-3.60$ & $.87 \pm 0.84$ \\
\hline III & $5.00-7.00$ & $6.33 \pm 1.15$ & $19.00-21.00$ & $20.00 \pm 1.41$ & $0.95-2.45$ & $1.62 \pm 0.76$ \\
\hline Average & $4.33-9.71$ & $7.11 \pm 1.34$ & $19.00-47.00$ & $32.16 \pm 10.68$ & $0.95-4.32$ & $2.58 \pm 0.80$ \\
\hline
\end{tabular}

SD - standard deviation 

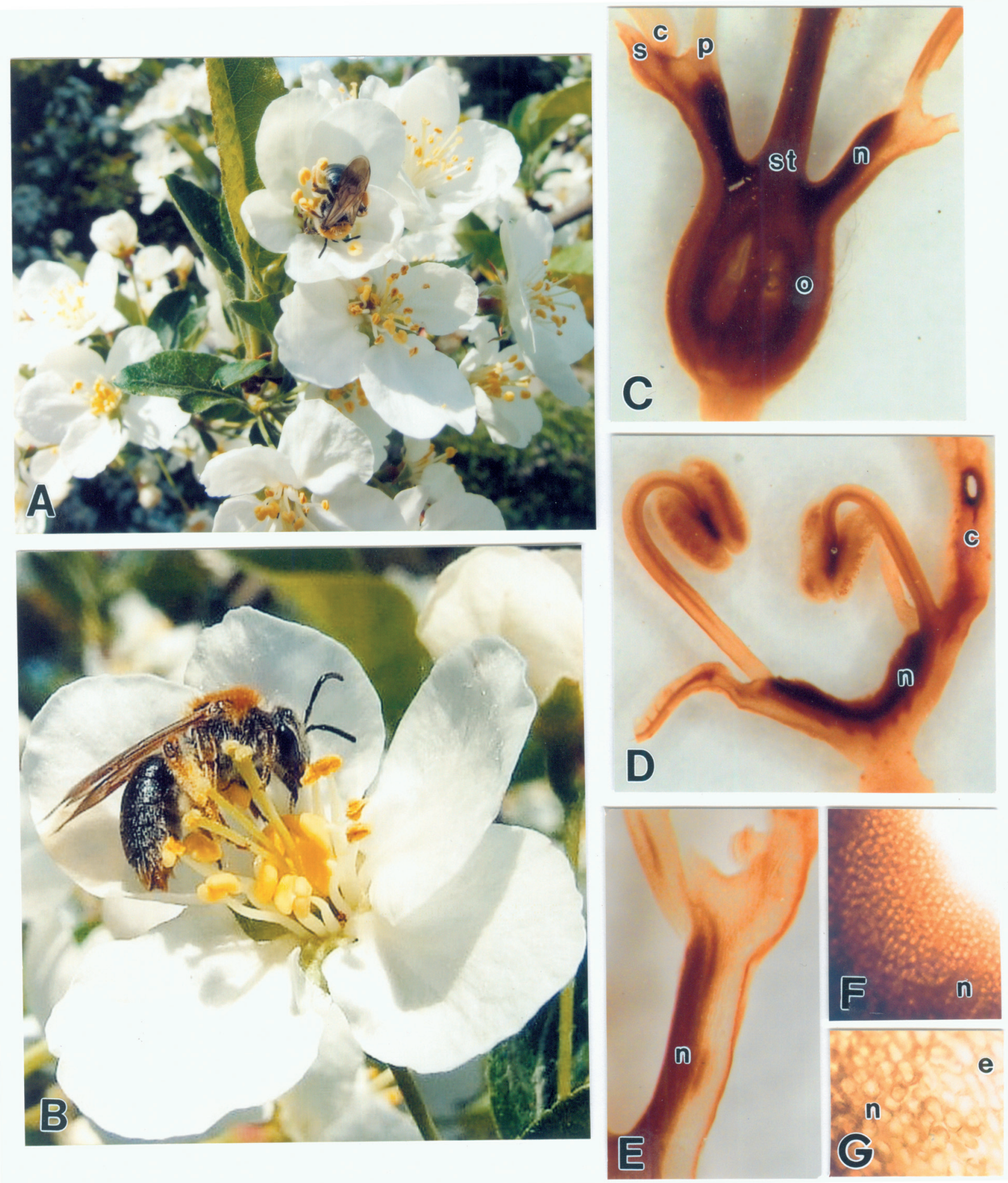

Fig. 1. Malus sargentii flowers and portions of their longitudinal sections.

A - Flowers developing on stems in great numbers at full bloom stage, x 1.5;

$\mathrm{B}$ - Flowers on the second day of flowering, $\mathrm{x} 4$;

C - Lower part of the flower with the visible nectary (n); st - style, o- ovary, p- stamen filament, $\mathbf{c}$ - petal, $\mathbf{s}$ - sepal, x 10;

D -Tangent section portion with the nectary $(\mathbf{n}), \mathrm{x} 11$;

E - Nectariferous layer (n) on the adaxial surface of the hypanthium, x 28;

F - Fine, isodiametric cells of the nectariferous tissue (n), x 90;

$\mathrm{G}-$ Cells of the glandular layer (n) and epidermis (e) of the nectary, x 180. 


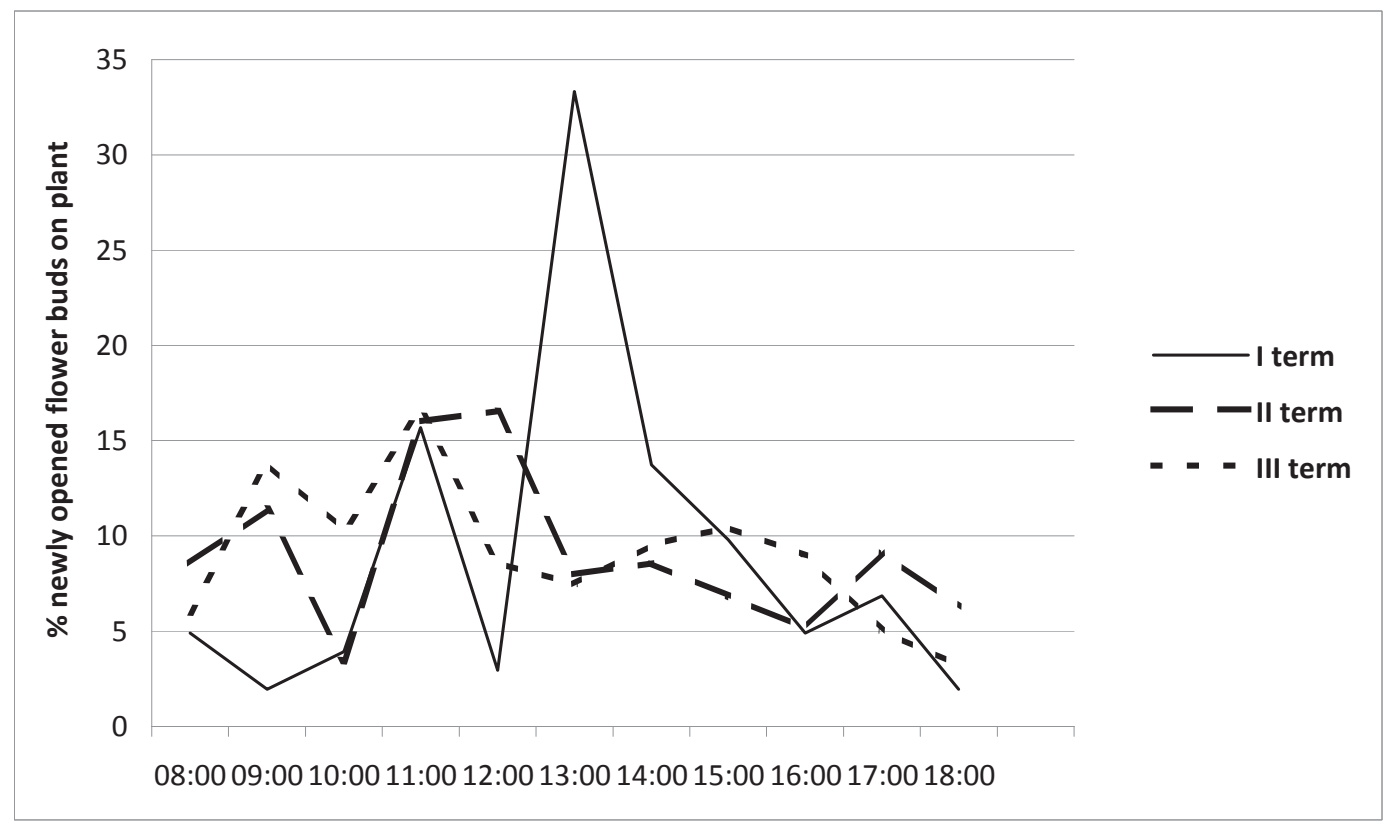

Fig. 2. Daily dynamics of opening Malus sargentii flowers in year 2008.

\section{Topography and size of the nectary}

Located in the adaxial part of the hypanthium, the orange-yellow nectary occupied the space between the base of the styles and the androecium. The multi-layered nectary gland lined the walls of a small cavity in which the nectar accumulated (Figs 1 C, D). Measured in longitudinal section of the flower, the upper diameter of the cavity was $2.5 \mathrm{~mm}$ with a height of $1.3 \mathrm{~mm}$, whereas the radial length of the nectariferous layer reached, on the average, $1.5 \mathrm{~mm}$ and its thickness was approx. 0.34 $\mathrm{mm}$. This layer had an even thickness along its whole length (Fig. $1 \mathrm{E}$ ). Due to the protrusion of the nectariferous layer on the hypanthium surface, the floral nectary of Malus sargentii was included in automorphic nectaries. The glandular layer of the nectary is composed of isodiametric cells (Figs 1 F, G) with a much smaller size than the cells making up the remaining part of the hypanthium. Vascular bundles, supplying the nectary, ran at the base of the glandular tissue (Figs 1 D, E).

\section{Micromorphology of the nectary}

When viewed by SEM, the epidermal cells of the lower part of the nectary were polygonal, equallydimensioned (Figs $3 \mathrm{~A}, \mathrm{C}$ ), and in the higher situated regions they were slightly elongated (Figs 3 A, B). At some places, they formed regular rows (Figs 3 A-D). Their surface was covered by a layer of cuticle with different ornamentation. At places, the surface of the cuticle showed regular, parallel striation (Figs $3 \mathrm{~A}, \mathrm{C}$ ), whereas in some other parts of the nectary surface its irregular folds were observed (Figs 3 A, D). A strongly protruding cuticle occurred on the epidermal cells sur- rounding the stomata (Figs $3 \mathrm{D}, 4)$. The stomata were few and they were found only in the lower part of the nectary, surrounding the base of the style (Fig. 3 A). They were arranged unidirectionally, along the axis of the flower. The stomata were surrounded by 5-7 epidermal cells and they were classified as the anomocytic type. They were situated in shallow depressions below the other cells of the epidermis. Around the stomata, epidermal cells were located with cuticular striae arranged radially relative to the stomata (Figs 3, 4). The cuticular striae partially overlapped the stomata, covering them from the outside.

In the material for SEM examination, sampled at the beginning of flowering, almost all the stomata were closed. In some of them, secretion traces were visible by the clenched cuticular ledges (Fig 4). The outer cuticular ledges were very well developed.

\section{The nectar production rate}

Intensive nectar production in the flowers took place between 8.00 and 14.00 , which was confirmed by the presence of numerous insects visiting the flowers. The nectar exuded from the stomata initially formed droplets and then it accumulated in the depression of the nectary, which was the place of the initial nectar presentation to insects.

It was demonstrated that the weight of nectar secreted by a single flower of Malus sargentii was $0.71 \mathrm{mg}$, on the average, and in particular investigations from $0.43 \mathrm{mg}$ up to $0.97 \mathrm{mg}$. The sugar content in the nectar reached $19-47 \%$, on the average ca. $32 \%$. The weight of sugars in the nectar secreted by a single flower was $0.26 \mathrm{mg}$ (Tab. 1). 

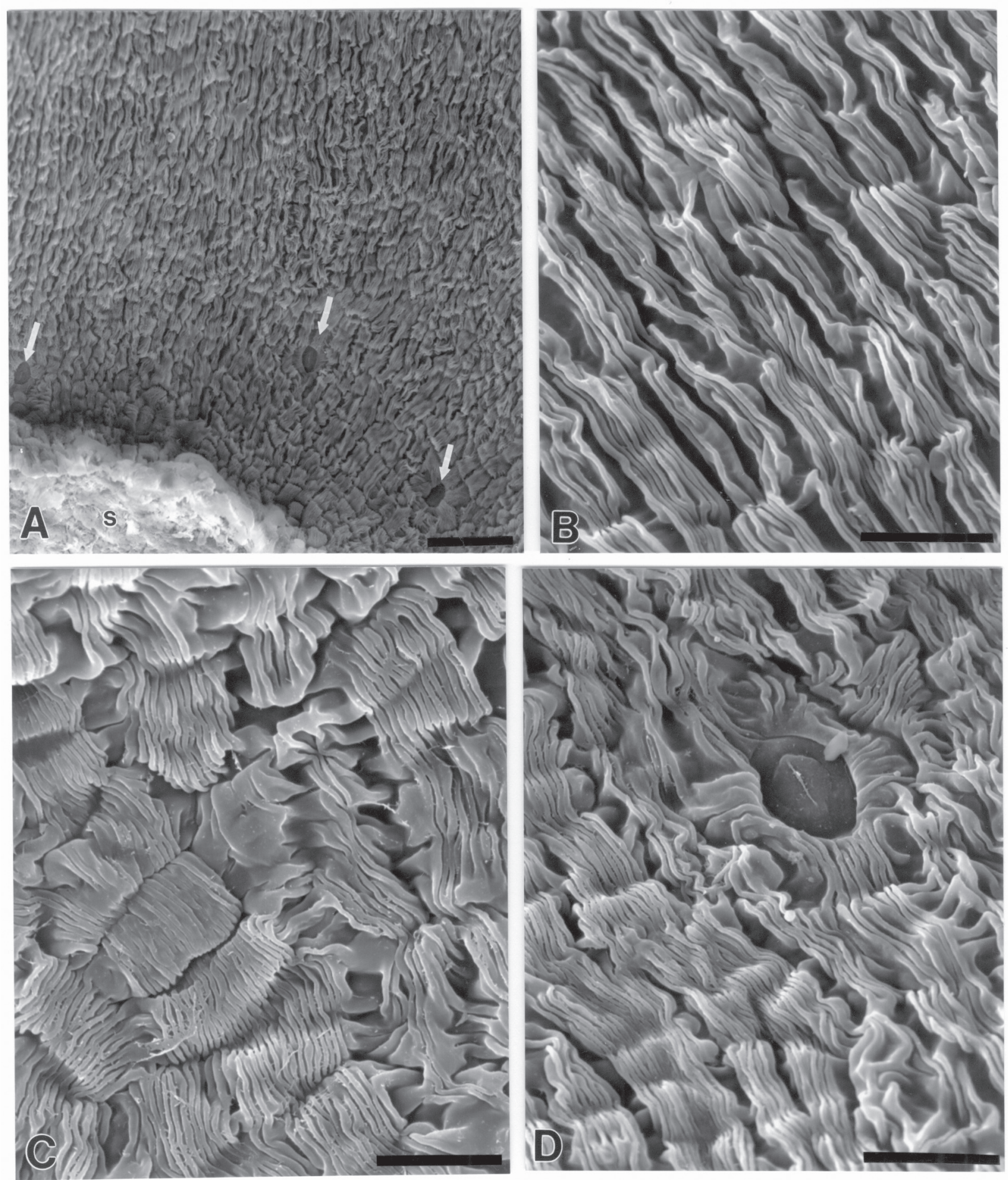

Fig. 3. Surface portions of the floral nectary of Malus sargentii.

A - Lower region of the nectary with stomata (arrows), bar $=100 \mu \mathrm{m}$;

B - Surface of epidermal cells from the upper part of the nectary with parallelly arranged cuticular striae, bar $=30 \mu \mathrm{m}$;

C, D - Variations in cuticle sculpture on the surface of epidermal cells in the lower part of the nectary, C - bar $=20 \mu \mathrm{m}$, $\mathrm{D}-\mathrm{bar}=30 \mu \mathrm{m}$. 

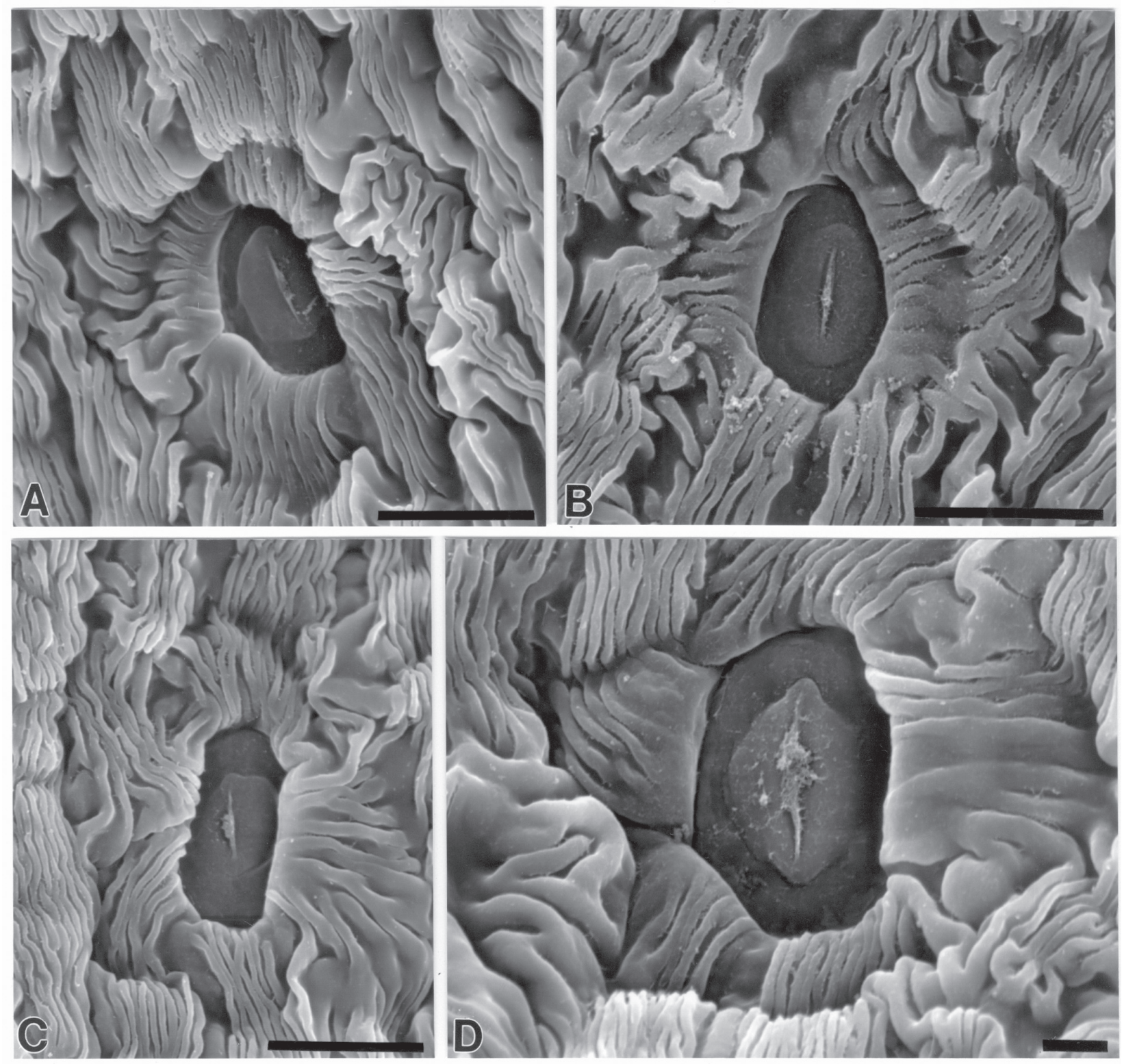

Fig. 4. Stomata from the lower part of the nectary of Malus sargentii.

A, B, C, D - Closed stomata on the first day of the flower blooming, surrounded by epidermal cells with radially arranged cuticular striae; the cuticle on the surface of some cells shows strong folding, A, B, C - bar $=20 \mu \mathrm{m}, \mathrm{D}-\mathrm{bar}$ $=10 \mu \mathrm{m}$. 


\section{DISCUSSION}

The floral nectaries of Malus form a fleshy layer located between the basal parts of the styles and the androecium. Smets (1986) and Bernardello (2007) classify the nectaries of Rosaceae as hypanthial nectaries, whereas Wery s z o-Chmiele w s k a et al. (2003) and Kon arska (2007) termed them as receptacular nectaries. Fahn (1979) classified them similarly. N a g y - D e ri et al. (2007) give yet another name to the nectary of Cydonia, describing it as the receptaculo-ovarial nectary. It seems however that, in accordance with the opinion of many researchers, the term "hypanthial nectaries" is appropriate. These nectaries belong to the main type of nectaria persistentia (S met s 1986), since, according to this author, they form a disc covering the surface of the hypanthium.

The surface of the epidermal cells of the nectary of Malus sargentii is covered by a distinct layer of cuticle, striated or irregularly undulate. $\mathrm{Nag}$ y $\mathrm{T}$ ó th et al. 2000 report that such a structure of the nectary surface can promote the even distribution of nectar. The type of cuticle striation on the floral elements can also contribute to different light effects, which are important for insects (K u g l e r , 1970). Cuticular striae can also scatter sunlight, protecting floral structures against excessive insolation ( J u n i p e r and J e f free, 1983).

Likewise in Malus sargentii, epidermal cells the nectary showing strong cuticle folding were found in several cultivars of commercial apple trees (O r o s z Kovács et al. 1990, Nagy Tóth et al. 2000). Chenomeles speciosa and Chenomeles japonica, also belonging to the subfamily Pomoideae, were characterised by strong folding of the cuticle of the nectary (W e r y s z k o-Ch mi e lew s ka et al. 1997). Distinct cuticle striation was also noted in several species of Crataegus (W e r y s z k o- C h mi e le w s k a et al. 2003).

A smooth surface of the cuticle covering the epidermal cells of the nectary of Malus sylvestris was observed by Konarska (2006). This author also showed a smooth structure of the nectaries in several Malus species grown as ornamental apple trees (K o narska, 2007). In our earlier studies, we observed a smooth surface of the cuticle also in Aronia melanocarpa (Pomoideae) (W e r y s z k oChmielew ska et al. 1997).

The stomata found in the epidermis of the nectary of Malus sargentii were similar to those which had been observed earlier in the nectaries of Aronia melanocarpa (W e r y s z k o - C h m i e l e w s k a et al. 1997) and Malus sylvestris (K o n a r s k a , 2006).

In the present study, it was shown that a single flower of Malus sargentii secreted within 5 days $0.43-0.97 \mathrm{mg}$ of nectar (on the average $0.71 \mathrm{mg}$ ) with a sugar concentration of $19-47 \%$ (on the average $32 \%$ ). The weight of sugars in the nectar was $0.26 \mathrm{mg}$. From flowers of the same species, S z k l a n o w s k a (1987) obtained nectar with a sugar content of $38.9 \%$ and the weight of sugars per flower was $0.32 \mathrm{mg}$. These values do not differ significantly from the results of our study and they prove not too abundant nectar production and sugar yield of this species compared to other taxa from the group of ornamental apple trees. S z k l a n o w s k a (1987) recorded the maximum sugar weight $(1.3 \mathrm{mg})$ in the case of Malus 'Gorgeous', which was a four times higher result than the one noted by this author for Malus sargentii. M a u r z i o and Grafl (1969) found that 2-6 $\mathrm{mg}$ of nectar, with a sugar content of $30-65 \%$, could be obtained within 24 hours from flowers of different Malus species. In extreme climatic conditions (Israel), a sugar concentration of $75-87 \%$ can be obtained. Much larger amounts of nectar from flowers of various cultivars of commercial apple trees were recorded by J a b ł on s ki (1986), who reports that one flower produces $2.2-18.5 \mathrm{mg}$ of nectar with a sugar content of 16-38\%. Gulyás et al. (1989) showed that the sugar concentration in the nectar of the apple trees investigated by them was 23-29\%.

In terms of quantity and sugar content, the nectar secreted by the flower of Malus sargentii can be compared to the nectar secreted by flowers of an ornamental apple tree Malus 'Wintergold' (S z k l a n o w s k a , 1987).

The thickness of the nectariferous layer of $M a$ lus sargentii is similar to the thickness of such layer in ornamental apple trees Malus baccata var. jackii and Malus x zumi 'Szafer', which were studied by K on a r s k (2007).

In Malus sargentii nectar exudation is effected primarily through the stomata of the nectary. In the case of the occurrence of a small number of stomata, one may presume that nectar is also secreted in another way, e.g. through microchanes in the cuticle, which was demonstrated by Radice and Galati (2003) in the case of the nectaries of Prunus persica. On the other hand, Orosz-Kovács et al. (1990) found that there were two modes of nectar secretion in $M a$ lus: through stomata as well as through the raised and disrupted cuticle of the nectary.

\section{Acknowledgments}

We would like to thank Mrs. Magdalena Michońska, MA, for her technical assistance in the preparation of slides for LM. We express our thanks to Mr. Marek Wróbel, Eng, for the preparation of slides and their documentation in SEM. 


\section{REFERENCES}

B e r n a rd e11o G., 2007. A systematic survey of floral nectaries. [In:] Nectaries and nectar. S. W. Nicolson, Nepi M., E. Pacini (eds.), Springer, Dordrecht.

B ug a ł a W., 2000. Drzewa i krzewy. Państwowe Wydawnictwo Rolnicze i Leśne, Warszawa.

Chwil M., Konarska A., Weryszko-Chmielewsk a E., 2006. Diversity of the floral nectaries surface of four Crataegus L. species. Acta Agrobot. 59 (1): 29-39.

Fa h n A., 1979. Ultrastructure of nectaries in relation to nectar secretion. Am. J. Bot. 66: 977-985.

Gadawski R. M., Smith S. M., 1992. Nectar sources and age structure in population of a Sedes provocans (Diptera: Culicidae). J. Med. Entom. 29 (5): 879-886.

Gulyás S., Nagyné Bíró M., Molnár Á., 1989. Nectar production of apple cultivars in the Nyírsg area and the composition of apple honey. Méhész Újság, 2 (1): 18-20.

Jabłoński B., 1986. Nektarowanie i wydajność miodowa ważniejszych roślin miododajnych w warunkach Polski cz. V. / Nectar secretion and honey efficiency of important honey plants in polish conditions. Pszczel. Zesz. Nauk. 30: 195-205.

Jabłoński B., Szklanowska K., 1979. Propozycje zmiany metody badań nektarowania roślin. / Improved method of investigations on nectar secretion of plants. Pszczeln. Zesz. Nauk. 23: 105-114.

Juniper B. E., Jeffree C. E., 1983. Plant Surfaces. Edward Arnold, London.

Kołtowski Z., 2006. Wielki atlas roślin miododajnych. Przedsiębiorstwo Wydawnicze Rzeczpospolita S.A., Warszawa.

Konarska A., 2006. Budowa nektarników jabłoni dzikiej (Malus sylvestris (L.) Mill.). / Studies on the structure of nectaries of wild apple (Malus sylvestris (L.) Mill.). Acta Agrobot. 59 (1): 41-48.

Konarska A., 2007. The comparison of nectaries structure of some varieties of ornamental apple. Acta Agrobot. 60 (1): 35-43.

Konarska A., Masierowska M., WeryszkoChmielewska E., 2005. The structure of nectaries and nectar secretion in common pear (Pyrus communis L.). J. Apic. Sci. 49 (1): 85-92.

Kugler H., 1970. Blütenökologie. Gustaw Fisher Verlag, Jena.

Maurizio A., Grafl I., 1969. Das Trachtpflanzenbuch. Nektar Und Pollen die wichtigsten Nahrungsquellen der Honingbiene, Ehrenwirth Verlag, München.

Nagy Tóth E. N., Bubán T., Hevesi M., OroszKovác Z., Szabó L., G., 2000. Morfological characteristics of the nectar and composition of nectar of selected apple cultivars. Acta Hort. 538 (1): 301-308.

Nagy-Deri H., Orosz-Kovác Zs., Farkas Á., 2007. Morfological characterization of the floral nectar in some apple-shaped quince cultivars. Acta Bot. Hung. 49 (3-4): 359-375.
Orosz-Kovác Z., Nagy Tóth E., Csatos A., Szabó A. 1990. A nektárium szerkezezet és a nektárprodukció összefúggés néhány almafajtánál. Bot. Közlem. 77 (1-2): 127-132.

Orosz-Kovác Z., Szabó L. G., Botz L., Bubán T., Majer Bordacs M., Nagy Tóth E., 1997. Sugar components and refraction of the floral nectar in apple cultivars. Hort. Sci. 29: 123-128.

Radice S., Galati B. G., 2003. Floral nectary ultrastructure of Prunus persica L. Batch cv. Forastero (Newcomer), an Argentine Peach. Plant Syst. Evol. 238: 23-32

S mets E., 1986. Localization and systematic importance of the floral nectarines in the Magnoliatae (Dicotyledons). Bull. Jard. Bot. Nat. Belg. 56: 51-76.

Szklanowska K., 1987. Pszczelarska wartość jabłoni ozdobnych stosowanych jako zapylacze w sadach. I The apicultural value of ornamental apple trees applied as pollinators in production orchards. Pszczeln. Zesz. Nauk. 31: 189-206.

Weryszko-Chmielewska E., Konarska A., 1995. Porównanie struktury nektarników wybranych gatunków z podrodziny Pomoideae (Rosaceae). / Comparison of the nectary structure of selected species from the subfamily Pomoideae. Acta Agrobt. 48 (1): 33-34.

Weryszko-Chmielewska E., Konarska A., 1996. Anatomia nektarników kwiatowych dziewięciu gatunków z podrodziny Pomoideae (Rosaceae). / Anatomy of floral nectaries of nine species from the subfamily Pomoideae. Acta Agrobot. 49 (1-2): 95-105.

Weryszko-Chmielewska E., Masierowska M., Konarska A., Pezda M., 1996. Wielkość nektarników i obfitość nektarowania niektórych gatunków Cotoneaster, Crataegus i Sorbus. / Nectaries dimensions and abundance of nectar secretion in some Cotoneaster, Crataegus and Sorbus species. Ann. Univ. Mariae Curie-Skłodowska, Sect. EEE, 17: 133-140.

Weryszko-Chmielewska E., Masierowska M., Konarska A., 1997. Surface of the nectaries and nectar production of four Pomoideae representatives (Rosaceae). Acta Hort. 437: 359-367.

Weryszko-Chmielewska E., Masierowska M. L., Konarska A., 2003. Characteristics of floral nectaries and nectar in two species of Crataegus (Rosaceae). Plant Syst. Evol. 238: 33-41

Weryszko-Chmielewska E., Konarska A., 2006. Micromorphology of Sorbus intermedia Pers. Nectary surface in different phases of blooming. Acta Agrobot. 59 (1): 49-59. 


\section{Charakterystyka kwitnienia, nektarników kwiatowych i nektaru Malus sargentii Rehd.}

\section{Streszczenie}

W warunkach Lublina (Poland) w latach 20072008 badano biologię kwitnienia Malus sargentii, jabłoni ozdobnej pochodzącej z Japonii. Określono dobową dynamikę rozkwitania kwiatów, długość kwitnienia oraz oblot kwiatów przez owady. Zbadano ilość nektaru wytwarzanego przez kwiat oraz zawartość cukrów w nektarze. W mikroskopie świetlnym i skaningowym elektronowym analizowano wielkość nektarników oraz mikromorfologię ich powierzchni. Stwierdzono, że najwięcej kwiatów rozwija się w godzinach 11.00 - 13.00. W tym samym czasie obserwo- wano największą liczbę owadów w kwiatach. Wśród owadów dominowały pszczoły (90\%), przy znacznie mniejszej liczbie trzmieli (6\%) i motyli (4\%). Długość życia kwiatu wynosiła 5 dni. W tym czasie kwiat wytwarzał średnio 0,71 mg nektaru o średniej zawartości cukrów wynoszącej 32\%. Nektarniki Malus sargentii mają barwę pomarańczowożółtą i reprezentują typ hypancjalny. Ze względu na uwypuklenie tkanki nektaronośnej zaliczono je do nektarników automorficznych. Powierzchnia komórek epidermy nektarnika odznaczała się wyraźnymi pofałdowaniami kutykuli. Nieliczne aparaty szparkowe zlokalizowane były tylko w bazalnej części nektarnika. Na początku kwitnienia wszystkie aparaty szparkowe były zamknięte, ale przy dobrze rozwiniętych zewnętrznych listwach kutykularnych obserwowano ślady wydzieliny. 